J. Egypt. Soc. Parasitol. (JESP), 50(3), 2020: 488-493

(Online: 2090-2549)

\title{
BEE VENOM DRUG POTENTIALITY ON THE MACROMOLECULES DAMAGE OF THE LARVAL GUT OF HERMETIA ILLUCENS (L.), (DIPTERA: STRATIOMYIDAE)
}

\author{
By
}

MAMDOUH I. NASSAR ${ }^{1}$, DINA H. ABD EL-MONEM ${ }^{1}$, MAI YOUSSEF ${ }^{2}$, SAMAR M. IBRAHIM ${ }^{3}$, SOHA M. MOHAMED ${ }^{4}$, MOHMED SALAH ABD-ALDAYEM ${ }^{5}$ AND EMAN ALAAELDIN ABDELFATTAH ${ }^{1}$

Department of Entomology ${ }^{1}$, and Biotechnology Program ${ }^{2}$, Faculty of Science, Cairo University, Central Laboratories, Faculty of Agriculture ${ }^{3}$, Cairo University, Children Cancer Hospital ${ }^{4}$, and Institute of Vaccines and Drugs ${ }^{5}$, Doki, Cairo Egypt

( ${ }^{\star}$ Correspondence: Mamdouh@sci.cu.edu.eg).

\begin{abstract}
Bee venom is a complex mixture of apamin, mast-cell degranulating peptide, phospholipase A2 and melittin proteins, which are responsible for multiple actions in biochemical reaction of different living organisms including insect. Black soldier fly (Hermetia illucens (L.), larvae have gained popularity both for their ability to decompose organic waste and serve as a source of proteins for domestic. Use of black soldier fly larvae (BSFL) is among the solutions being explored to shift the value chain in organic waste management by producing valuable products. Monitoring of possible impact of bee venom was assessed using mortality rate and biochemical parameters such as protein carbonyls amount, and lipid peroxides concentration. The potential use of protein carbonylation, and lipid peroxidation as a biomonitoring method of bee venom potentiality was proposed. Concentrations of protein carbonyls of $H$. illucens gut samples treated with $1 \mathrm{mg} / \mathrm{ml}$ bee venom are significantly increased than control samples. The lipid peroxidation level in gut of $5^{\text {th }}$ instar insect treated with $1,0.5,0.25, \& 0.125 \mathrm{mg} / \mathrm{ml}$ were 65 , $57,46, \& 34$, respectively, compared to control. Bee venom specific antioxidant activity caused comparable adverse effects in the organisms inhabiting concentration up to $1 \mathrm{mg} / \mathrm{ml}$.

Key words: Bee venom, Protein carbonylation, Lipid peroxidation, Hermetia illucens, Mortality.
\end{abstract}

\section{Introduction}

Black soldier fly (Hermetia illucens (L.), Diptera: Stratiomyidae) larvae (BSFL) have gained popularity both for their ability to decompose organic waste and as a source of proteins for domestic livestock (Erickson et al, 2004; Liu et al, 2008, Diener et al, 2009; Nguyen et al, 2009; Diener et al, 2011b; Bullock et al, 2013; Banks et al, 2014). Use of black soldier fly larvae (BSFL) is among solutions being explored to shift the value chain in organic waste management by producing valuable products (Isibika et al, 2019). Chen et al. (2006) characterized the major active components of honey bee venom as apamin, mast-cell degranulating peptide, phospholipase A2 and melittin (Lima and Brochetto, 2003). The major active components of bee venom are apamin, mast-cell components (Hider, 1988; Charles, 2005). Golden (1989) and Mazdak et al. (2004) re- degranulating peptide, phospholipase A2 and melittin (Lima and Brochetto, 2003). The content of liquid bee venom compared to dry bee venom slightly differed (Bogdanov, 2012). The bee venom had insecticidal and hemolytic activities against the grain weevil Sitophilus granarius (L.) and cricket insect nymphs (Jerome et al, 2001). When bees sting, an alarm pheromone stimulated more bees to target attack (Collins et al, 1982; Evans, 1985; Kastberger et al, 1998). But, bee immune system depends on the defense reaction (Glinski and Buczek, 2003).

The bee venom challenged the larvae of Senotainia tricupis, Mermis sp. and parasitic mites, Acarapis varroa jacobsoni (Rose and Briggs, 1969; Blum, 1978; Hoffman, 1996; Glinski and Jarosz, 2001). Toxicity reaction of the bee venom was due biological active ported the melittin compound was responsible for the venom toxicity. Infrared (IR) 
spectrum and chemical analysis of melittin suggested the presence of glycerol (Schneider et al, 1991; Kodaka, 1998; Taroni et al, 2000; Wright et al, 2002). Also, Apis mellifera venom contains several toxins of peptides and proteins (Nakajima 1986; Edstrom, 1992). The mammalian toxicity by the bee venom was recorded by Schmidt (1986) and Meier (1995) that the $\mathrm{LD}_{50}$ was $(2.8 \mathrm{mg} / \mathrm{kg})$ and for human (500-1500) sting. The bee venom was suggested as an Api-therapy tool to be considered for various diseases control including bacteria and virus (Nassae and Elzayat, 2019; 2020; Nassar et al, 2020). Bee venom has oral anti-amoebic effect with loaded CS nanoparticles more effective than subcutaneous injection (Saber et al, 2017). It inhibited growth and survival of pathogenic bacterial strains (Nassar et al, 2018).

This work aimed to study the Biorational and physiological effects of crude bee venom of Apis mellifera on the black soldier fly, Hermetia illucens (L.).

\section{Materials and Methods}

The bee venom of Apis mellifera was kindly obtained from Institute of Vaccines and Serum, Doki, Giza Egypt. Bee venom was dissolved in distilled water for the concentration series.

Insect rearing: The black soldier fly, Hermetia illucens was obtained from the colony in Qalyobia Governorate. Larval stages were maintained in the laboratory for several generations where reared on fruits waste (banana peels), at $27-30^{\circ} \mathrm{C}, 80 \%$ R.H (Diener et al, 2009).

Bee venom toxicity to $5^{\text {th }}$ black solider fly larvae: Bee venom was dissolved in definite distilled water and leaf dip method was adopted. Fresh banana peels were cut into small pieces and dipped in $250,500,750 \&$ $1000 \mathrm{ppm}(0.25,0.5,0.75 \& 1 \mathrm{mg} / \mathrm{ml}$ bee venom) concentrations to treat black soldier fly $5^{\text {th }}$ instar larvae. Treated peels were applied to $5^{\text {th }}$ instar larvae as a mere feeding source. Three replicates were maintained for each treatment with 10 larvae per replicate. After 48 hours of treatment, the larvae were continuously maintained on non-treated fresh banana peel discs. Larval mortality was recorded after $24 \mathrm{hrs}$ of treatment. The experiment was conducted at $27 \pm 2{ }^{\mathrm{O}} \mathrm{C}, 65 \pm 5 \%$ R.H. with photoperiod of $16: 8 \mathrm{hr}$. (L:D). Mortality\% was corrected according to Abbott's formula (1925) as follows:

Observed mortality \% - control mortality $\%$
Probit analysis was determined to calculate the median lethal concentration $\left(\mathrm{LC}_{50}\right)$ value and related parameters. Finney (1971) using a software computer program (SAS, 2002) to represent the regression lines.

Protein carbonyls assay: Procedure used (Levine et al, 1990) for protein carbonyls assay was adopted with little-described modifications. After tissue isolation, samples were homogenized in $5 \mathrm{ml}$ ice-cold phosphate buffer after homogenization (mortar, 10 strokes/30seconds), samples were centrifuged at $2000 \times g$ for $10 \mathrm{~min}$ at $4^{\circ} \mathrm{C}$. For a tissue extract, $800 \mu \mathrm{L}$ aliquot of the supernatant was transferred to a clean microtube with ncentration was measured (Hermes-Lima et $a l$, 2004). Gut was isolated in phosphate
$200 \mu \mathrm{l}$ of $10 \mathrm{mM}$ 2, 4-dinitrophenyl hydrazine (DNPH) prepared in $2 \mathrm{M} \mathrm{HCl}$. Samples were incubated for 30 minutes at room temperature, precipitated with $10 \%$ Tricholoro-acetic acid (TCA), and left for $10 \mathrm{~min}$ at $4^{\circ} \mathrm{C}$. Samples were centrifuged at $5000 \times g$ for 7 min at $4^{\circ} \mathrm{C}$. Pellet was washed four times with an ethanol/ethyl acetate (1:1) mixture, and re-dissolved in $1 \mathrm{ml}$ of sodium phosphate buffer. Absorbance was measured at $366 \mathrm{~nm}$, and rate of protein carbonyls concentration was expressed as $\mathrm{OD} / \mathrm{mg}$ protein. Blank was similarly prepared and treated as above but without adding DNPH.

Lipid peroxides assay: Lipid peroxides cobuffer ( $\mathrm{pH}$ 7.0), and homogenized in icecold methanol $(1: 5, \mathrm{w} / \mathrm{v})$. After homogeniza- 
tion (mortar, 10 strokes/30 seconds), samples were centrifuged at $2000 \mathrm{~g}$ for $10 \mathrm{~min}$ at $4^{\circ} \mathrm{C}$. A $5 \mathrm{~mL}$ aliquot of the supernatant was used for the assay. The following components were added to samples $(200 \mu 1$ of supernatant): $400 \mu \mathrm{l}$ of $1 \mathrm{mM} \mathrm{FeSO}_{4}, 200 \mu \mathrm{l}$ of $0.25 \mathrm{M} \mathrm{H}_{2} \mathrm{SO}_{4}$, \& $200 \mu \mathrm{l}$ of $1 \mathrm{mM}$ xylenol orange. Samples were incubated in dark conditions at room temperature for $3 \mathrm{hr}$. Absorbance was measured at $580 \mathrm{~nm}$. Then, $10 \mu 1$ of $0.5 \mathrm{mM}$ cumene hydroperoxides (an internal standard) was added to each sample, and maintained at room temperature for $1 \mathrm{hr}$ before absorbance was re-measured at $580 \mathrm{~nm}$. Absorbance change due to an internal standard addition was calculated. Lipid peroxides concentration was expressed as mM cumene hydroperoxides $/ \mu \mathrm{g}$ protein. Total protein concentration of was spectrophotometrically determined (Bradford, 1976), with Coomassie Brilliant Blue (COBB). $0.9 \mathrm{ml}$ of dye reagent $(10 \mathrm{mg}$ COBB $+5 \mathrm{ml}$ methanol $+10 \mathrm{ml}$ $85 \%$ O-phosphoric acid, completed to $100 \mathrm{ml}$ with distilled water) were added to $0.1 \mathrm{ml}$ of each sample in a separate test tube. The contents were mixed by gentle shaking and left to stand for $2 \mathrm{~min}$. Protein sample OD was measured at $595 \mathrm{~nm}$ against a blank of a tube containing distilled. Bovine serum albumin
(BSA) fraction V (Sigma-Aldrich) dissolved in $0.15 \mathrm{M} \mathrm{NaCl}$ was used as protein standard.

\section{Results}

Effect of bee venom on protein carbonyls and lipid peroxides: Relative levels of protein carbonyls and lipid peroxides in $5^{\text {th }}$ instar of $H$. illucans collected from different sites were given. Treated insects with 4 different bee venom concentrations (0.125$1 \mathrm{mg} / \mathrm{ml}$ ) showed significant increase in protein carbonyls and lipid peroxide level compared to the control insects. The increase was significantly correlated with the concentration of bee venom. A strong positive correlation among lipid peroxide content in the gut and bee venom concentration was found. The lipid peroxides concentrations were the highest in insects treated with $1 \mathrm{mg} / \mathrm{ml}$ bee venom. Lowest values were recorded mainly in insects treated with $0.125 \mathrm{mg} / \mathrm{ml}$. Increase of protein carbonyls amount in $5^{\text {th }}$ instar $H$. illucens treated with $1 \mathrm{mg} / \mathrm{ml}$ was significantly higher than control one. Mean values of protein carbonyls amount in gut insect feed on food with concentration of bee venom $0.125,0.25,0.50,1 \mathrm{mg} / \mathrm{ml}$ were $1.5,2.1,2.3$, $\& 2.4$ times higher than control values, respectively. Details were given in tables $(1 \&$ 20 and figures ( $1 \& 2)$

Table 1: Pearson's correlation coefficient, regression analysis among macromolecules (proteins, and lipids) damage (protein carbonyls, and lipid peroxides) in gut homogenates of $5^{\text {th }}$ instar of H. illucens and venom $(0.125,0.25,0.50, \& 1 \mathrm{mg} / \mathrm{ml})$.

\begin{tabular}{|l|l|l|}
\hline Item & Protein carbonyls amount & Lipid peroxides \\
\hline Regression equation & $\mathrm{Y}=0.366 \mathrm{e}^{0.118 \mathrm{x}}$ & $\mathrm{Y}=0.076 \mathrm{x}+0.059$ \\
\hline Correlation coefficient & $0.958^{* *}$ & $0.983^{* *}$ \\
\hline Type of equation & Exponential & Linear \\
\hline Chi square $\left(\mathrm{R}^{2}\right)$ & 0.975 & 0.966 \\
\hline Significance & 0.0001 & 0.0001 \\
\hline
\end{tabular}

Table 2: Sublethal \& lethal actions on $5^{\text {th }}$ instar larvae of black soldier fly treated with different venom concentrations

\begin{tabular}{|c|c|c|c|c|c|}
\hline \multirow{2}{*}{ LC } & \multirow{2}{*}{ ppm } & \multicolumn{2}{|c|}{$95 \%$ Fiducial limits } & \multirow{2}{*}{ Slope } & \multirow{2}{*}{$\mathrm{Chi}^{2}$} \\
\cline { 3 - 4 } & & Lower & Upper & & \\
\hline 10 & 241.8 & 157.5 & 309.8 & & \\
\hline 25 & 459.3 & 374.7 & 532 & & \multirow{2}{*}{$2.1788 \pm 0.3307$} \\
\hline 40 & 716.9 & 622.9 & 850 & 5.638 \\
\hline 50 & 936.9 & 798 & 1193.7 & & \\
\hline 75 & 1911 & 1432.6 & 3177.3 & & \\
\hline 90 & 3630 & 2372.1 & 7842.1 & & \\
\hline
\end{tabular}

\section{Discussion}

In the present study, $\mathrm{LC}_{10}, \mathrm{LC}_{25}, \mathrm{LC}_{40} \&$ $\mathrm{LC}_{50}$ for $5^{\text {th }}$ instar was $241.8,459.3,622.9 \&$ $936.9 \mathrm{ppm}$, respectively. The fit of the transformed data was acceptable using the chi- squared test. From the present results, it is indicated that the $5^{\text {th }}$ instar was more susceptible to bee venom. The results agreed with Greenberg et al. (2008) who showed that natural venoms from Solenopsis invicta were 
check the efficacy of venom with different doses against Argentine ants. Dose killed $50 \%$ population $\left(\mathrm{LD}_{50}\right)$ of Linepithema $h u$ mile and other species of ants were evaluated. L. humile was the most susceptible to venom species. Lai et al. (2012) check the efficacy of fire ant venoms against the larvae of Plutella xylostella under laboratory conditions. Venoms of Fire ant were applied topically, on dorsal region of thorax of $4^{\text {th }}$ instar larvae. The introduction of venoms in larval body resulted black coloration, flaccid paralysis, contractile and then larval death. $P$. xylostella larvae were most susceptible against fire ant venom. $\mathrm{LD}_{50}$ value was 3.9 $\& 3.3 \mu \mathrm{g} /$ insect after $24 \& 72 \mathrm{hr}$. on Sytophilus granarius respectively (Nassar, 2013).

The oral $L_{50}$ for orally active insecticidal peptide (OAIP-1) from venom of the Australian tarantula, Selenotypus plumipes in the agronomically important cotton bollworm Helicoverpa armigera was $104.2 \pm 0.6 \mathrm{pmol} /$ $\mathrm{g}$, which was the highest activity reported for an insecticidal venom peptide (Hardy et $a l, 2013)$. By venom injection in larvae of blow fly, caused quick paralysis, two different anti-insect toxins (LqhaIT \& Bj-xtrIT) elucidated from scorpions. Using engineering baculo viruses with cDNAs encoding (LqhIT2 as depressant toxin, and LqhIT1 as excitatory toxin), toxic genes were verified and improved insecticidal action (Froy et al, 2000). Insecticidal activity of peptide fractions (3-5KD) extracted from Odontobuthus odonturus (Arachnida: Buthidae) venom reported (Tahir et al, 2014).

The 3-5KD peptides were tested against Bactrocera zonata (Tephritidae: Diptera) under controlled environment. Different venom concentrations were applied using topical bioassay, on the dorsal side of fruit flies. The $\mathrm{LD}_{50} \& \mathrm{LD}_{70}$ values were $6.54 \mu \mathrm{l}$ and $18.85 \mu 1$ respectively (Tahir et al, 2014). The calculated mortality \% for all topical application of crude honey bee venom on $3^{\text {rd }}$ instar larvae of lesser wax moth Achroia grisel$l a$ were $8 \%$ at low concentration and $52 \%$ at high concentration. LC $_{50}$ was $38.27 \mu \mathrm{g} / \mu \mathrm{l}$
(Mahgoub et al, 2018). Compared with spider, snake and scorpion venoms were weaker, but centipede venom was quite active against Manduca sexta. None of these venoms were active orally, but several spider venoms were toxic topically at greatly exaggerated levels (Quistad et al, 1992).

Many spider venoms cause serious toxicity to the larvae when applied topically, as Diabrotica $u$. undecimpunctata spider venom topically on Manduca sexta larvae (Quistad et al, 1992). Bee venom had potentials to be used in IPM programs, and had insecticide activities against cricket nymph (Jerome et $a l, 2001)$. Also, survival of the bee depended on toxic defense against predators, insects and mites (Glinski and Buczek, 2003). Mortality of $S$. granaries adults by venom was due to its bioactive protein and peptide components (Nassar, 2013). Rose and Briggs (1969) reported that the secretions of hypopharyngeal gland secretions of young honey bee workers contained proteins. These secretions had bacteriostatic and bactericidal to many bacterial species. Venom challenged many saprophytic and pathogenic organisms (bacteria \& viruses), parasites (Senotainia tricupis, Mermis sp.) \& mites, Acarapis varroa jacobsoni (Glinski and Jarosz, 2001). Toxicity affected sensory organs (Hider, 1988). Hoffman (1996) and Charles (2005) found that venom toxicity effects on different organisms were due to CNS parlay- sis, or hemorrhagic or hemolytic effect. $\mathrm{LC}_{50}$ non-human was $2.8 \mathrm{mg} / \mathrm{kg}$ and man was 500 1500 sting (Schmidt and Ibrahim, 1994).

\section{Conclusion}

The outcome results proved successful biorational biochemical parameters as a biomonitoring tool of bee venom application on Hermetia illucens larvae.

\section{References}

AbdelFattah, EA, Augustyniak, M, Yousef, H A, 2017: Biomonitoring of genotoxicity of industrial fertilizer pollutants in Aiolopus thalassinus (Orthoptera: Acrididae) using alkaline comet assay. Chemosphere 182:762-70.

Aebi, H, 1984: Catalase in vitro. Meth. Enzy ol. 105:121-6. 
Ahmad, S, 1995: Oxidative stress from environmental pollutants. Arch. Insect Biochem. Physiol 29, 2:135-57.

Asada, K, 1984: Chloroplasts: Formation of active oxygen and its scavenging. Meth. Enzymol. 105:422-9.

Augustyniak, M, Juchimiuk, J, Przybyłowicz, WJ, Mesjasz-Przybyłowicz, J, Babczyńska, A, et al, 2006: Zinc-induced DNA damage and the distribution of metals in the brain of grasshoppers by the comet assay and micro-PIXE. Comp. Biochem. Physiol. Toxicol. Pharma. 144, 3:24251.

Banks, IJ, Gibson, WT, Cameron, MM, 2014: Growth rates of black soldier fly larvae fed on fresh human feces and their implication for improving sanitation. Trop. Med. Int. Hlth. 19:1422.

Bullock, N, Chapin, E, Elder, B, Evans, A, Givens, M, et al, 2013: Implementation of black soldier fly breeding and chicken feed production at Pickard's Mountain Eco-Institute.

Chen, YN, Li, KC, Li, Z, Shang, GW, Liu, D, et al, 2006: Effects of bee venom peptidergic components on rat pain-related behaviors and inflammation. Neuroscience 138, 2:631-40.

Diener, S, Solano, NMS, Gutiérrez, FR, Zurbrügg, C, Tockner, K, 2011: Biological treatment of municipal organic waste using black soldier fly larvae. Waste Biomass Valoriz. 2: 357-63.

Diener, S, Zurbrügg, C, Tockner, K, 2009: Conversion of organic material by black soldier fly larvae: establishing optimal feeding rates. Waste Manag. Res., 27: 603-10.

Erickson, MC, Islam, M, Sheppard, C, Liao, J, Doyle, MP, 2004: reduction of Escherichia coli O157: H7 and Salmonella enterica serovar enteritidis in chicken manure by larvae of the black soldier fly. J. Food Prot. 67:685-90.

Finney, DJ, 1971: Probit analysis. $3^{\text {rd }}$ edition. Cambridge University Press, London.

Froy, O, Zilberberg, N, Chejanovsky, N, Anglister, J, Loret, E, et al, 2000: Scorpion neurotoxins: structure/function relationships and application in agriculture. Pest Manage. Sci. 56, 5:472-4.

Greenberg, L, Kabashima, JN, Allison, CJ, Rust, MK, Klotz, JH, et al, 2008: Lethality of red imported fire ant venom to Argentine ants and other ant species. Ann. Entomol. Soc. Am. 101, 6:1162-8.

Hardy, MC, Daly, NL, Mobli, M, Morales,
RA, King, GF, 2013: Isolation of an orally active insecticidal toxin from the venom of an Australian Tarantula. PLos ONE 8, 9:e73136.

Hermes-Lima, M, 2004: Oxygen in biology and biochemistry: role of free radicals. Funct. Meta. Regulat. Adapt. 1: 319-966.

Isibika, A, Vinnerås, B, Kibazohi, O, Zurbrügg, C, Lalander, C, 2019: Pre-treatment of banana peel to improve composting by black soldier fly (Hermetia illucens (L.), Diptera: Stratiomyidae) larvae. Waste Manage. 100:151-60.

Lai, LC, Kuo, TC, Huang, RN, Wu, WJ, 2012: The insecticidal activities of fire ant (Hymenoptera: Formicidae) venoms against Plutella xylostella (Lepidoptera: Plutellidae) larvae. J. Econ. Entomol. 105, 5:1591-6.

Levine, RL, Garland, D, Oliver, CN, Amici, A, Climent, I, et al, 1990: Determination of carbonyl content in oxidatively modified proteins. Meth. Enzymol. 186:464-78.

Lima, PR, Brochetto, BMR, 2003: Hymenoptera venom review focusing on Apis mellifera. J. Venom. Anim. Toxins Includ. Trop. Dis. 9, 2:149-62.

Liu, Q, Tomberlin, JK, Brady, JA, Sanford, MR, Yu, Z, 2008: Black Soldier Fly (Diptera: Stratiomyidae) larvae reduce Escherichia coli in dairy manure. Environ. Entomol. 37: 1525-30.

Mahgoub MO, Lau WH, Omar DB, EI Naim AM, 2018: Evaluation the toxicity of honey bee venom on Achroia grisella developmental stages. World J. Agric. Res. 6, 1:5-9.

Nassar, MI, 2013: The potential of natural venom of Apis mellifera for the control of grains weevil adults (Sitophilus granarius; Coleoptera: Curculionidae). Inter. J. Entomol. Res. 10, 1: 25-31

Nassar, MI, Elzayat, EM, 2019: The cancer diseases and potentiality of bee venom toward therapeutic tools antitumor. CPQ Med. 7, 3:10-7. Nassar, MI, Elzayat, EM, 2020: Anti-cancer and anti-microbial and neurological effects using wasp venom peptides agents: Review, ACTA Sci. Microbiol. 3, 1: Nassar, MI, Mohamed, SM, Ibrahim, SM, 2020: Coronavirus COVID-19 detection, symptoms, spread and prevention. J. Clin. Immunol. Microbiol. JCIM-1, 1:1-8.

Nassar, MI, Youssef, ME, Abdel Mawgoud, D, Helal, SF, Kamel, HMM, 2018: Effect of honey bee venom against intensive care units' environmental pathogens. Egypt. J. Exp. Biol.

(Bot), 14, 2:237-44.

Nguyen, TN, Davis, DA, Saoud, IP, 2009: 
Evaluation of alternative protein sources to replace fish meal in practical diets for juvenile tilapia, Oreochromis spp. J. World Aquac. Soc. 40:113-21.

Nguyen, TN, Tomberlin, JK, Vanlaerhoven, S, 2015: Ability of black soldier fly (Diptera: stratiomyidae) larvae to recycle food waste. Environ. Entomol. 44: 406-10.

Quistad, GB, Dennis, PA, Skinner, WS, 1992: Insecticidal activity of spider (Araneae), centipede (Chilopoda), Scorpion (Scorpionida), and sna ke (Serpentes) venoms. J. Econ. Entomol. 85, 1: 33-9.

Rhoden, CR, Wellenius, G, Ghelfi, E, Lawrence, J, Gonzalez, B, 2005: PM induced cardiac oxidative stress is mediated by autonomic stimulation. Biochem. Biophys. Acta 172: 305-13.

Saber AE, Abdelwahab, AK, El Amir, AM, Nassar, MI, Zohdi, HF, 2017: Bee venom loaded chitosan nanoparticles as treatment for amoebiasis in mice. J. Egypt. Soc. Parasitol. 47, 2: 443-58.

SAS, 2002: SAS /STAT User's Guide, Version 9.1, Ed. SAS Institute Inc. Cary.

Schmidt, GH, Ibrahim, NM, 1994: Heavy metal content $\left(\mathrm{Hg}^{2+}, \mathrm{Cd}^{2+}, \mathrm{Pb}^{2+}\right)$ in various body parts: its impact on cholinesterase activity and binding glycoproteins in the grasshopper $\mathrm{Ai}$ olopus thalassinus adults. Ecotoxicol. Environ. 29:148-64.

Shinkai, Y, Li, S, Kikuchi, T, Kumagai, Y, 2015: Participation of metabolic activation of 2 , 4, 6-tri-nitrotoluene to 4-hydroxylamino-2, 6dinitrotoluene in hematotoxicity. J. Toxicol. Sci. 40, 5:597-604.

Shukla, AK, Pragya, P, Chowdhuri, DK, 2011: A modified alkaline comet assay for in vi vo detection of oxidative DNA damage in Dros- ophila melanogaster. Mut. Res. Gen. Toxicol. Environ. Mutat. 726, 2:222-6.

Tahir, HM, Kinza, Z, Rabia, M, Sajida, N, Abida, B, et al, 2014: Scorpion venom peptides for the management of Bactrocera zonata (Dipt era: Tephritidae). Wld. Appl. Sci. J. 32, 2:322-4. Upton, M, Mantle, B, Hastings, A, 2010: Methods for collecting, preserving and studying insects and other terrestrial arthropods. Australian Entomological Society.

Vij, P, 2015: Environmental Pollution: Its effects on life and its remedies. Nat. J. Manage Tech. (NJMT), 3, 2:88-92.

Wuana, RA, Okieimen, FE, 2011: Heavy metals in contaminated soils: A review of sources, chemistry, risks and best available strategies for remedation. ISRN Ecology doi.org/10.5402/ $\underline{402647}$

Yousef, HA, AbdelFattah, EA, Augustyniak, M, 2017: Evaluation of oxidative stress biomarkers in Aiolopus thalassinus (Orthoptera: Acrididae) collected from areas polluted by the fertilizer industry. Ecotoxicology 26, 3:340-50.

Zhang, Y, Sun, G, Yang, M, Wu, H, Zhang, J, et al, 2011: Chronic accumulation of cadmium and its effects on antioxidant enzymes and malondialdehyde in Oxya chinensis (Orthoptera: Acridoidea). Ecotoxicol. Environ. Safety 74, 5: 1355-62.

Zhou, Q, Zhang, J, Fu, J, Shi, J, Jiang, G, 2008: Biomonitoring: an appealing tool for assessment of metal pollution in the aquatic ecosystem. Anal. Chim. Acta 606, 2:135-50.

Zhu, H, Zhang, J, Kim, MT, Boison, A, Sedykh, A, et al, 2014: Big data in chemical toxicity research: The use of high-throughput screening assays to identify potential toxicants. Chem. Res. Toxicol. 27, 10:1643-51.

\section{Explanation of figures}

Fig.1: Effect of bee venom on protein carbonyls amounts (OD/mg protein) in gut homogenates of Hermetia illucens. Mean values marked with different small letters significantly different among control and treated insects $(\mathrm{P}<0.05)$.

Fig. 2: Effect of concentration of bee venom with respect to control site on lipid peroxides concentration (mM cumene hydroperoxide/mg protein) in gut homogenates of Hermetia illucens.

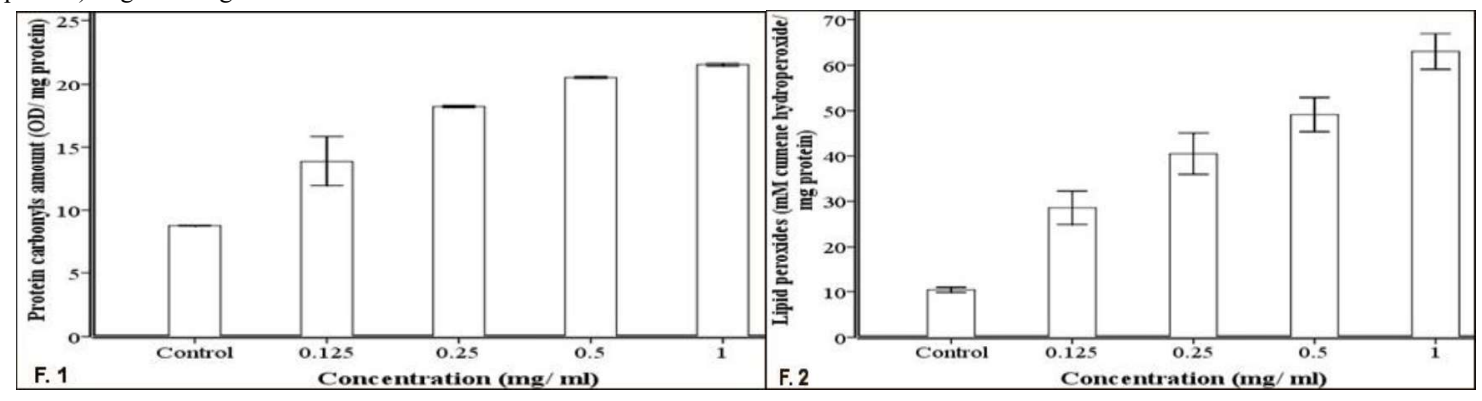

